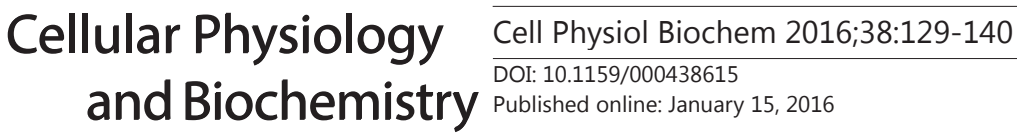

Accepted: November 09, 2015

This article is licensed under the Creative Commons Attribution-NonCommercial-NoDerivatives 4.0 Internafor commercial purposes as well as any distribution of modified material requires written permission.

\title{
Aquaporin-3 Inhibition Reduces the Growth of NSCLC Cells Induced by Hypoxia
}

\author{
Shu-Ying Hou ${ }^{a}$ Yan-Ping $\mathrm{Li}^{\mathrm{b}}$ Jin-Hua Wang ${ }^{\mathrm{a}}$ Song-Ling Yang ${ }^{\mathrm{c}}$ Ying Wang ${ }^{\mathrm{a}}$ \\ Yang Wang ${ }^{\text {a }}$ Ye Kuang ${ }^{d}$
}

\begin{abstract}
aDepartment of Pharmacy Intravenous Admixture Service, The First Affiliated Hospital of Harbin Medical University, Harbin, bepartment of Endodontics, The First Affiliated Hospital of Harbin Medical University, Harbin, 'Department of Biology Pharmacy, Heilongjiang Vocational College of Biology Science and Technology, Harbin, dDepartment of Gynecology and Obstetrics, The Second Affiliated Hospital of Harbin Medical University, Harbin, China
\end{abstract}

\section{Key Words}

Non-small cell lung cancer • Aquaporin-3 • HIF-1 1 • VEGF • ERK

\begin{abstract}
Background/Aims: Non-small cell lung cancer (NSCLC) is the leading cause of death worldwide. Although aquaporin-3 (AQP3) is widely distributed in mammalian tissues and over-expressed in NSCLC cells, there are limited studies on the effects of AQP3 knockdown on NSCLC cells under hypoxic conditions. Methods: The CCK-8 assay was used to calculate cell viability. Scratch-wound healing and transwell assays were used to detect cell migration and invasion. Apoptotic cells were measured by the TUNEL assay. mRNA expression levels were calculated via quantitative RT-PCR. Relative protein levels were determined by immunoblot assays. Results: AQP3 knockdown substantially reduced proliferation, migration, and invasion of A549 and $\mathrm{NCl}-\mathrm{H} 460$ cells under hypoxic conditions. Moreover, AQP3 knockdown clearly induced cell apoptosis. Further analysis identified levels of HIF-1 $\alpha$, VEGF, Raf, phosphor-MEK, and phosphor-ERK, whose activities were significantly attenuated in the AQP3 knockdown group. Conclusions: These findings indicate that AQP3 knockdown retards the growth of NSCLC cells partially through inhibiting HIF-1 $\alpha$ /VEGF and Raf/MEK/ERK signalling pathways.
\end{abstract}

\section{Introduction}

Lung cancer is a common and lethal malignancy, and it accounts for 1.59 million deaths annually. With the development of antitumour drugs, one-year all-stage survival has been increasing. However, five year survival has remained unchanged. The incidence of non-small

S.-Y. Hou and Y.-P. Li contributed equally to this work.

Ye Kuang

KARGER 


\section{Cellular Physiology Cell Physiol Biochem 2016;38:129-140 \begin{tabular}{ll|l} 
and Biochemistry Published online: January 15, 2016 & $\begin{array}{l}\text { @ 2016 The Author(s). Published by S. Karger AG, Basel } \\
\text { www.karger.com/cpb }\end{array}$ \\
\hline
\end{tabular} Hou et al.: Aquaporin-3 Knockdown Retards the NSCLC Cells Growth}

cell lung cancer (NSCLC) accounts for approximately 85\% of all lung cancers [1]. Therefore, clarifying the pathogenesis and finding new therapeutic targets is crucial.

Aquaporins (AQPs) are small, intrinsic membrane proteins that facilitate the transport of water across cell plasma membranes and are involved in numerous physiological as well as pathophysiological processes [2]. Currently, 13 isoforms of mammalian AQPs have been identified in various tissues [3-5]. AQPs are notably abundant in aggressive tumours [6-8] and their expression is closely correlated with the severity of histological tumours. Recent evidence has shown that AQPs play an essential role in tumour cell proliferation, migration, and even tumour angiogenesis $[9,10]$. The AQP AQP3 is widely distributed in mammalian tissues, especially in human neoplastic tissues, and is markedly dysregulated in breast cancer [11], colorectal carcinoma [12] and lung cancer [13]. Recently, several studies have shown that AQP3 plays a critical role in tumour growth, cell proliferation, cell invasion [9, $14,15]$, and other cellular processes in various cancers. Shen et al. [16] have documented that $\mathrm{AQP} 3$ regulates proliferation, invasion and even migration in gastric carcinoma cells by disrupting E-cadherin activation. A recent study has demonstrated that an AQP3 knockdown suppresses tumour growth and angiogenesis in experimental NSCLC cells under normoxic conditions [17].

Hypoxia is a common phenomenon that occurs in most human tumours and has been shown to be associated with proliferation, invasion, and migration [18-20]. However, the effects of AQP3 on NSCLC cells under hypoxic conditions have not been studied. Therefore, this study sought to explore the effects of AQP3 and determine the underlying mechanisms in the effects of AQP3 knockdown on NSCLC cells under hypoxic conditions.

\section{Materials and Methods}

\section{Cell Culture}

The NSCLC A549 (adenocarcinoma) and NCI-H460 (large cell carcinoma) cell lines were from the American Type Culture Collection (ATCC) and were cultured in RPMI 1640 supplemented with 10\% (v/v) foetal bovine serum. Briefly, exponentially growing cells were maintained at $37^{\circ} \mathrm{C}$ in a $5 \% \mathrm{CO}_{2} / 95 \%$ air incubator. For hypoxic exposure, cells were cultured in a Concept 400 anaerobic incubator (Ruskinn Technology Ltd., Bridgend, UK, E.U.) under $1 \% \mathrm{O}_{2} / 5 \% \mathrm{CO}_{2} /$ balanced $\mathrm{N}_{2}$ and incubated at $37^{\circ} \mathrm{C}$.

\section{RNA interference}

To knock down the AQP3 gene, cells were starved for $12 \mathrm{~h}$ to normalize any group differences before treating the cells with small interfering RNA (siRNA) for $24 \mathrm{~h}$. Then, A549 and NCI-H460 cells were transfected with the siRNA, which was designed and synthesized by Invitrogen. Non-targeted control siRNA (siRNA-NC) was used as a negative control. The siRNAs duplexes targeted AQP3 (siRNA-1, siRNA-2, and siRNA-3) and the non-targeted control siRNA were as follows: AQP3 siRNA-1: (sense) 5'-CCU CUG GAC ACU UGG AUA UTT-3', (antisense) 5'-AUA UCC AAG UGU CCAG AGGTT-3'; siRNA-2: (sense) 5'-CUG UAU UAU GAU UGG AUAU TT-3', (antisense) 5'-AGC CUA AUA CUU CCA GAG GTT-3'; siRNA-3: (sense) 5'-GGC UGU AUU AUG AUG CAA UTT-3', (antisense) 5'-AUU GCA UCA UAA UAC AGC CTT-3'; non-targeted siRNA: (sense) 5'-UUC UCC GAA CGU GUC ACGU-3', (antisense) 5'-ACG UGA CAC GUU CGG AGAA-3'. Briefly, cells grew to 80\% confluence, and then $1 \mu \mathrm{g}$ of siRNA and $10 \mu \mathrm{l}$ of the X-tremeGene siRNA Transfection Reagent was mixed with serum-free Opti-MEM medium. The mixture was incubated at room temperature for $20 \mathrm{~min}$ and then was added directly onto the cells; this was followed by a $24 \mathrm{~h}$ incubation at $37^{\circ} \mathrm{C}$.

\section{Cell Counting Kit-8}

The cell viability was calculated using the Cell Counting Kit-8 (CCK-8) (Beyotime Biotechnology, Jiangsu, China) according to the manufacturer's protocol. Briefly, the A549 and NCI-H460 cells were seeded on 96-well plates in RPMI 1640 with $10 \%$ foetal bovine serum for $24 \mathrm{~h}$. Then, the cells were transfected at $80 \%$ confluence using siRNAs against AQP3 for $24 \mathrm{~h}$. Finally, the viable cells were detected using the Cell Counting Kit-8, where the absorbance for each sample was calculated at $450 \mathrm{~nm}$ using a microplate reader (TECAN, Salzburg, Austria). 


\section{Cellular Physiology Cell Physiol Biochem 2016;38:129-140 \begin{tabular}{ll|l}
\cline { 2 - 2 } DOI: 10.1159/000438615 & (C) 2016 The Author(s). Published by S. Karger AG, Basel
\end{tabular} and Biochemistry Published online: January 15, 2016 www.karger.com/cpb \\ Hou et al.: Aquaporin-3 Knockdown Retards the NSCLC Cells Growth}

Scratch-Wound assay

The confluent A549 and NCI-H460 cells cultured in 6-well plates were scratched by pipette tips, which led to a 1-mm-wide lane per well, and the remaining cells were washed with PBS. Then, the cells were treated with 10\% FBS in RPMI 1640 containing siRNA. Wounded areas were measured at time point zero and after the $24 \mathrm{~h}$ treatment; photographs were taken of the same areas recorded at time point zero.

\section{Cell migration and invasion analysis}

For the migration assay, cells were transfected with siRNA and incubated for $24 \mathrm{~h}$, and then resuspended cells were placed in the top layer of the transwell chamber with $8 \mu \mathrm{m}$ pores (Millipore). The lower layer of the chamber contained $10 \%$ FBS as a chemoattractant. The chambers were maintained at $37^{\circ} \mathrm{C}$ in $5 \% \mathrm{CO}_{2}$ for $24 \mathrm{~h}$. Non-migrating cells on the top of the membrane were removed with cotton swabs. Cells that had migrated to the bottom were fixed with $95 \%$ ethanol, stained with $0.2 \%$ crystal violet (Sigma), photographed, and counted. Each experiment was performed in triplicate (magnification, $\times 200$ ). Matrigelcoated transwell inserts (Millipore) were used in the cell invasion assay. After a $24 \mathrm{~h}$ treatment, cells that invaded the lower layer of the transwell membrane were fixed, stained, and counted (magnification, $\times 200$ ).

\section{TUNEL assay}

The DNA fragmentation in A549 and NCI-H460 cells was measured by using a commercially available kit (Cell Death Detection Kit, Roche Biochemicals, Mannheim, Germany) as described previously [21]. Briefly, the cells were fixed with $4 \%$ paraformaldehyde at room temperature and cleaned with phosphatebuffered saline (PBS), and then permeabilized with $1 \%$ Triton $\mathrm{X}-100$ at $4^{\circ} \mathrm{C}$. Then, each slide was treated with the TdT-labelled nucleotide mix and maintained at $37^{\circ} \mathrm{C}$ for $1 \mathrm{~h}$ in the dark. Finally, slides were rinsed and then counterstained with $10 \mathrm{mg} / \mathrm{ml} \mathrm{4,6-diamidino-2-phenylindole} \mathrm{(DAPI)} \mathrm{at} 37^{\circ} \mathrm{C}$. The fluorescence staining was viewed with laser scanning confocal microscopy (FV300, Olympus, Japan). TUNEL positive cells were counted in five fields (200 × magnification).

\section{Immunoblot Analysis}

Total protein extracts were isolated from A549 and NCI-H460 cells. The protein extracts were separated with $10 \%$ SDS-PAGE and then blotted onto a nitrocellulose membrane, then blocked with $5 \%$ non-fat milk at room temperature for $1 \mathrm{~h}$. Then, the membranes were probed with primary antibodies for HIF-1 $\alpha$, Raf, total-MEK and total-ERK, phosphor-MEK and phosphor-ERK (Cell Signalling Technology, Danvers, MA, USA), AQP3, tubulin, VEGF (Abcam Inc., Cambridge, USA) and GAPDH (Kangcheng Bio-tech Inc., Shanghai, China), and incubated overnight at $4^{\circ} \mathrm{C}$. Membranes were rinsed three times for 10 min with PBS containing 0.5\% Tween-20, and incubated with a secondary antibody (Alexa Fluor, Molecular Probes, Eugene, OR, USA) for $1 \mathrm{~h}$ at room temperature. Western blot bands were scanned by Imaging System (LICOR Biosciences, Lincoln, NE, USA) and detected by Odyssey v3.0 software in each group and normalized to GAPDH as an internal control.

RNA isolation and quantitative reverse transcription-PCR ( $q R T-P C R$ )

qRT-PCR was performed to measure the mRNA expression of HIF- $1 \alpha$ and VEGF in A549 and NCI-H460 cells. Briefly, total RNA was isolated from cell lines using TRIzol reagent (Invitrogen) according to the manufacturer's instructions. Total RNA $(1 \mu \mathrm{g})$ was reverse-transcribed in a $20 \mu \mathrm{l}$ volume at $37^{\circ} \mathrm{C}$ for $15 \mathrm{~min}$ and $98^{\circ} \mathrm{C}$ for 5 min using ReverTra Ace qPCR RT Kit (TOYOBO CO., LTD, Osaka, Japan). The PCR reactions were performed with real-time PCR Master Mix. The cDNA sample quality was assessed using an ABI PRISM 7500HT unit (Applied Biosystems, CA, USA). The cycle threshold (CT) fluorescence values were calculated using the SDS 2.4 software (Applied Biosystems). The relative expression of VEGF and HIF- $1 \alpha$ were normalized to GAPDH using the $2^{-\triangle \Delta C t}$ method. All primers (Invitrogen) were as follows: VEGF sense primer: 5'- TAC CTC CAC CAT GCC AAGTG-3', antisense primer: 5'-TGA TGA TTC DTG CCC TCC TCC-3'; HIF- $1 \alpha$ sense primer: 5'-CTG AGG TTG GTT ACT GTT GGT ATC-3', antisense primer: 5'-AGT GTA CCC TAC TAG CCG AGGA-3'; GAPDH sense primer: 5'-AAG AAG GTG GTG AAG CAGGC-3', antisense primer: 5'-TCC ACC ACC CAG TTG CTGTA-3'.

Statistical analysis

The values are expressed as the mean \pm SEM. One-way ANOVA was used for statistical analyses followed by Bonferroni's test using a two-tailed $p<0.05$ as statistically significant. 


\section{Cellular Physiology Cell Physiol Biochem 2016;38:129-140 \begin{tabular}{c|c|c|} 
DOI: 10.1159/000438615 & $\begin{array}{l}\text { O } 2016 \text { The Author(s). Published by S. Karger AG, Basel } \\
\text { www.karger.com/cpb }\end{array}$ \\
\hline
\end{tabular}

\section{Results}

\section{Aquaporin 3 (AQP3) knockdown reduced $A 549$ and NCI-H460 cell proliferation}

To determine whether AQP3 was involved in the proliferation of NSCLC cells, A549 and $\mathrm{NCI}-\mathrm{H} 460$ cells were transfected with specific siRNA targeting AQP3. The protein expression of endogenous AQP3 was markedly reduced by siRNA-3 compared with siRNA-NC in A549 cells (Fig. 1A). Similar effects were also identified in NCI-H460 cells (Fig. 1B). Based on the above results, siRNA-3 was selected for the following experiment. As shown in Fig. 2, siRNA-3 against AQP3 substantially reduced cell proliferation under hypoxic conditions in both cell lines (Fig. 2). This result demonstrated that AQP3 plays a role in proliferation under hypoxic conditions.

\section{AQP3 downregulation retarded $\mathrm{A} 549$ and $\mathrm{NCI}-\mathrm{H} 460$ cell migration}

To further determine whether cell migration was regulated by AQP3, a scratch-wound assay and a transwell migration assay were conducted. The A549 cells transfected with AQP3 siRNA exhibited a significant decrease in cell migration after a $24 \mathrm{~h}$ incubation (Fig. 3B and F). The representative images are shown in Fig. 3A and E. Similarly, in the NCI-H460 cells

A
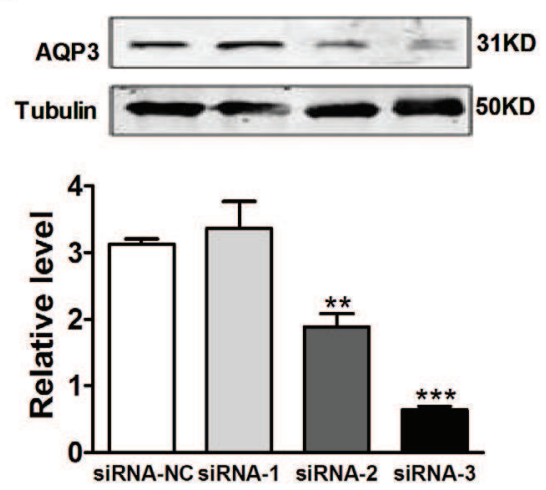

B
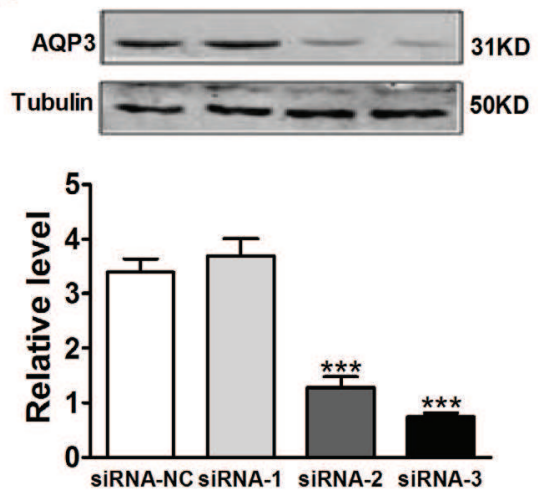

Fig. 1. Effect of siRNA knockdown of Aquaporin 3 (AQP3) on protein expression of AQP3. The A549 and NCI-H460 cells were cultured and transfected with AQP3 siRNA-1 siRNA-2 or siRNA-3. Twenty-four hours after transfection, the protein expression of AQP3 was detected in A549 cells (A) and NCI-H460 cells (B). All of the values are denoted as the mean \pm SEM; ${ }^{* *} p<0.01$ or ${ }^{* * *} p<0.001$ vs. siRNA-NC, $\mathrm{n}=3$ independent experiments.

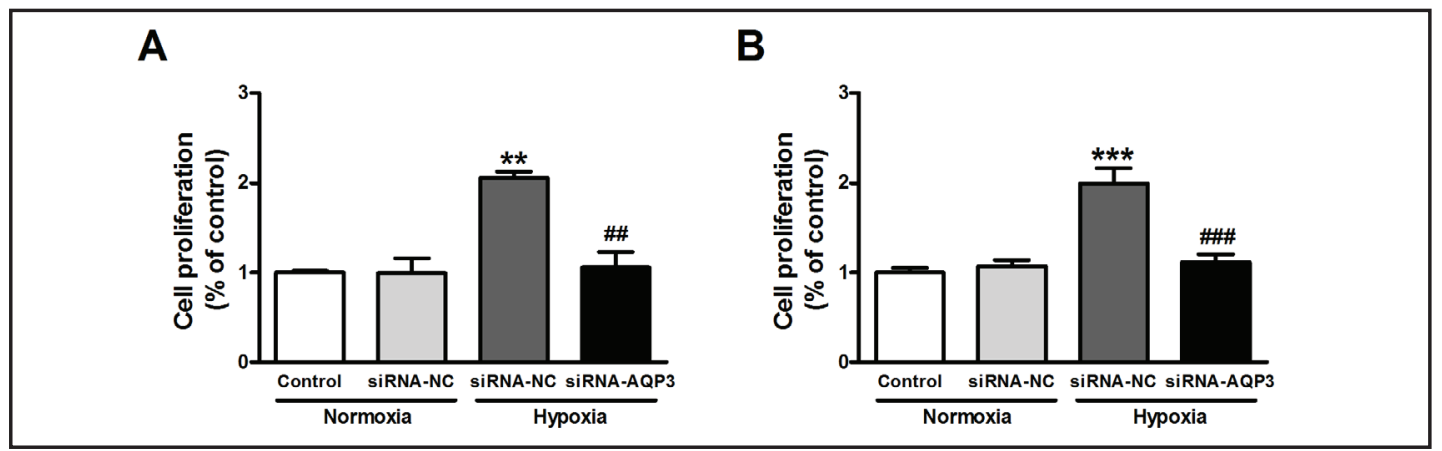

Fig. 2. Effect of AQP3 on hypoxia-induced proliferation in A549 and NCI-H460 cells. The A549 and NCIH460 cells were cultured and transfected with AQP3 siRNA or non-targeted control siRNA. Twenty-four hours later, cell proliferation was determined by CCK-8 in A549 cells (A) and NCI-H460 cells (B). All of the values are denoted as the mean $\pm \mathrm{SEM}^{* *} p<0.01$ or ${ }^{* * *} p<0.001$ vs. siRNA-NC of normoxia, \#\#p $<0.01$ or \#\#\# $p<0.001$ vs. siRNA-NC of hypoxia, $\mathrm{n}=6$ independent experiments. 


\section{Cellular Physiology Cell Physiol Biochem 2016;38:129-140

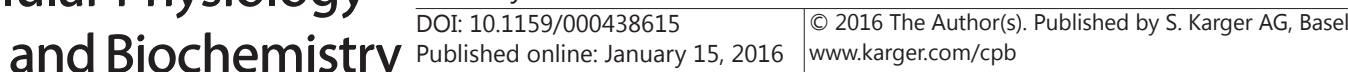

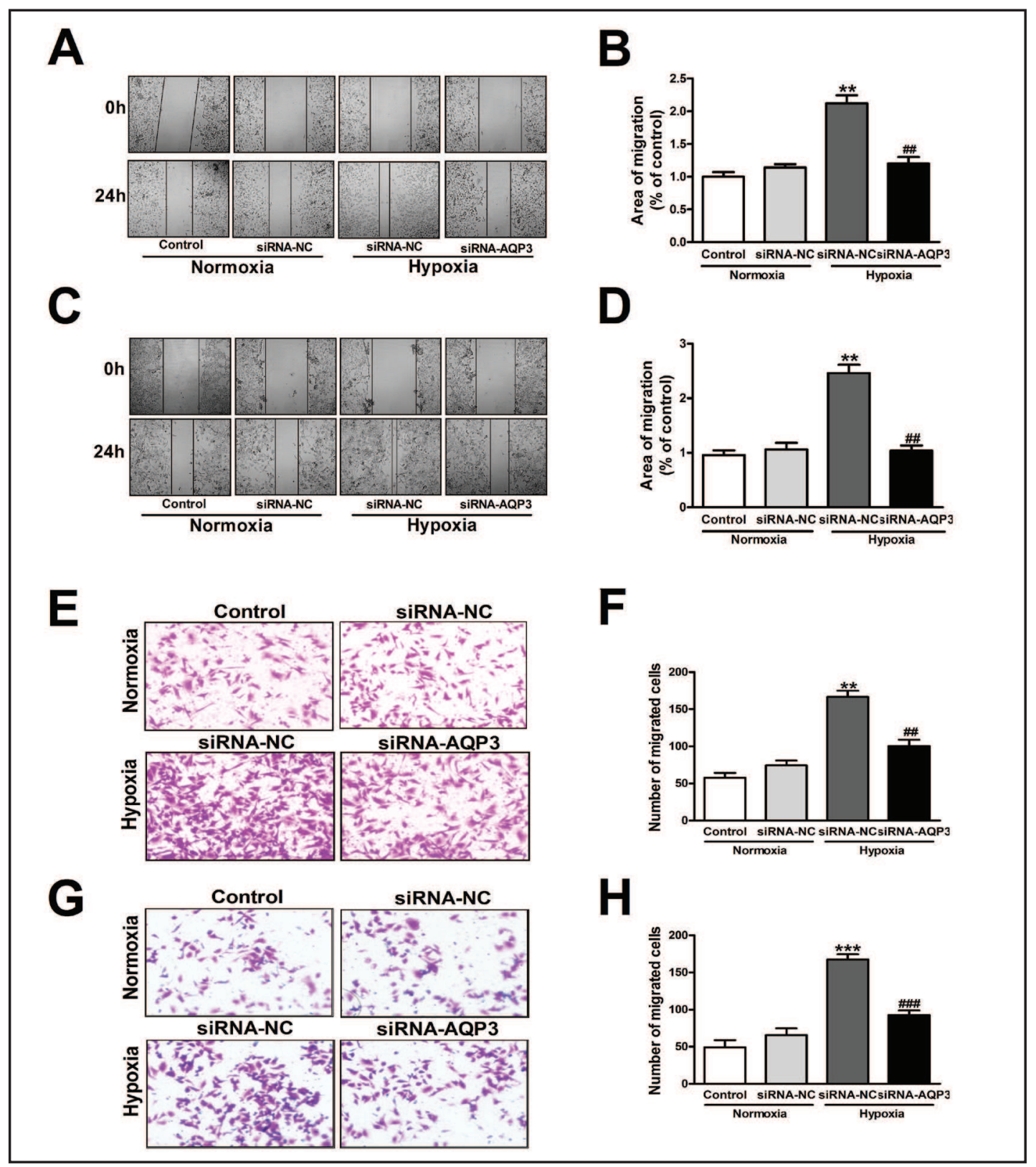

Fig. 3. Effect of AQP3 on hypoxia-mediated migration in A549 and NCI-H460 cells. Images showing migration changes after treatment with the AQP3 siRNA in scratch-wound and transwell migration assays for A549 (A, E) and NCI-H460 cells (C, G). Migration promotion of endogenous AQP3 was dominantly blocked by siRNA in A549 (B, F) and NCI-H460 cells (D, H). All values are denoted as the mean \pm SEM; ** $p<0.01$ or *** $p<0.001$ vs. siRNA-NC of normoxia, \#\# $p<0.01$ or \#\#\# $p<0.001$ vs. siRNA-NC of hypoxia, $\mathrm{n}=6$ independent experiments.

treated with AQP3 siRNA, cellular migration was reversed nearly to normal levels (Fig. 3D and $\mathrm{H}$ ). The photographs are shown in Fig. 3C and G. These results indicated that a significant down regulation of cellular migration was correlated with the reduced expression of AQP3 in A549 and NCI-H460 cells exposed to hypoxia.

Endogenous AQP3 knockdown retarded cell invasion and facilitated apoptosis

The transwell assay verified that AQP3 knockdown inhibited cell invasion. Representative images are shown in Fig. 4A and B, respectively. The proportions of invasive KARGER 


\section{Cellular Physiology Cell Physiol Biochem 2016;38:129-140 \begin{tabular}{ll|l|l|}
\hline DOI: 10.1159/000438615 & O 2016 The Author(s). Published by S. Karger AG, Basel \\
\hline
\end{tabular}

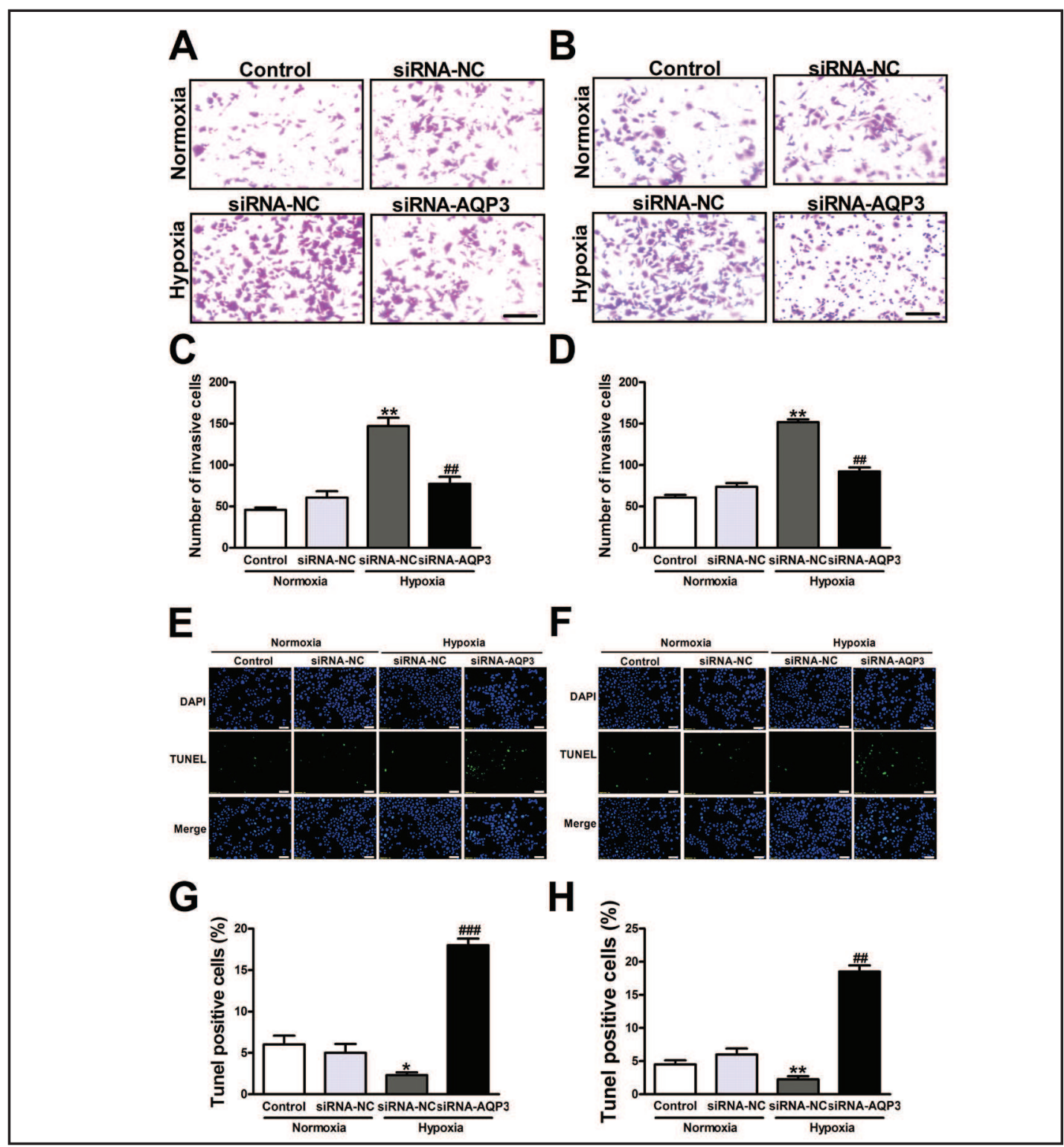

Fig. 4. Effect of AQP3 knockdown on invasion and apoptosis in A549 and NCI-H460 cells. Photographs represent the cells passing through the Matrigel in an invasion assay in A549 (A) and NCI-H460 cells (B). The histogram shows that AQP3 knockdown substantially reduced cell invasion after transfection with the AQP3 siRNA for $24 \mathrm{~h}$ in A549 (C) and NCI-H460 cells (D). The TUNEL assay studies show that AQP3 knockdown induced cells apoptosis. The representative images are shown for A549 (E) and NCI-H460 cells (F). Quantitative analysis was performed to document that AQP3 knockdown significantly enhanced the number of apoptotic nuclei in A549 (G) and NCI-H460 cells (H). All of the values are denoted as the mean \pm SEM; $* p<0.05$ or ${ }^{* *} p<0.01$ vs. siRNA-NC of normoxia, \#\# $p<0.01$ or \#\#\# $p<0.001$ vs. siRNA-NC of hypoxia, experiments were repeated six times.

A549 cells were dramatically decreased (59.92\%) after treatment with the AQP3 siRNA (Fig. 4C). Similarly, the invasive proportions of the NCI-H460 cells were reduced to $38.32 \%$ after AQP3 knockdown (Fig. 4D). The apoptotic cells were measured with the TUNEL assay. The A549 and NCI-H460 cells were cultured and transfected with AQP3 siRNA or non-targeted control siRNA. Twenty-four hours after transfection, high TUNEL positive cells were present in AQP3 siRNA treated A549 and NCI-H460 cells. The representative images are shown in Fig. 4E and $\mathrm{F}$ and the quantified results of cell apoptosis are shown in Fig. 4G and H. 


\section{Cellular Physiology Cell Physiol Biochem 2016;38:129-140 \begin{tabular}{ll|l}
\hline DOI: 10.1159/000438615 & O 2016 The Author(s). Published by S. Karger AG, Basel \\
\hline
\end{tabular}

Fig. 5. Effect of $A Q P 3$ knockdown on mRNA and levels of HIF- $1 \alpha$ and VEGF. Quantitative real-time PCR was performed to verify that AQP3 knockdown substantially reduced the mRNA levels of HIF- $1 \alpha$ and VEGF in A549 (A, E) and NCI-H460 cells (C, $\mathrm{G})$. Moreover, the corresponding levels of HIF- $1 \alpha$ and VEGF was detected by western blot. Protein levels of HIF- $1 \alpha$ and VEGF were significantly decreased in A549 (B, F) and NCI-H460 cells (D, H). All of the values are denoted as the mean \pm SEM; ${ }^{* *} p<0.01 v s$. siRNA-NC of normoxia, \#\# $p<0.01$ vs. siRNA-NC of hypoxia, experiments were repeated six times.
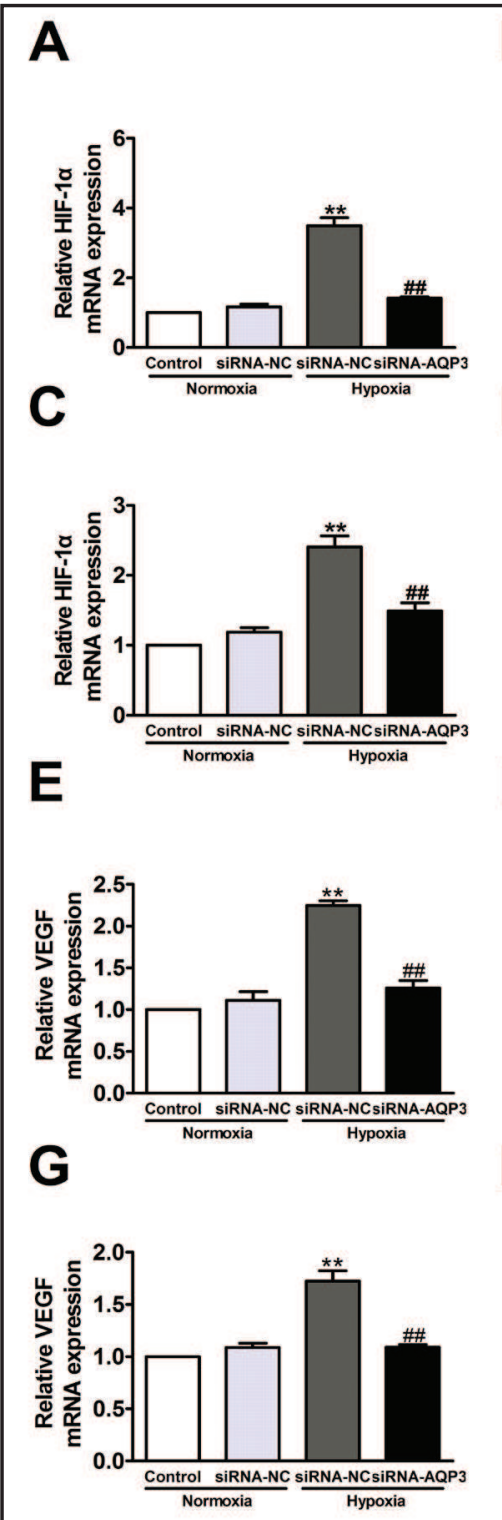

\section{$F$}
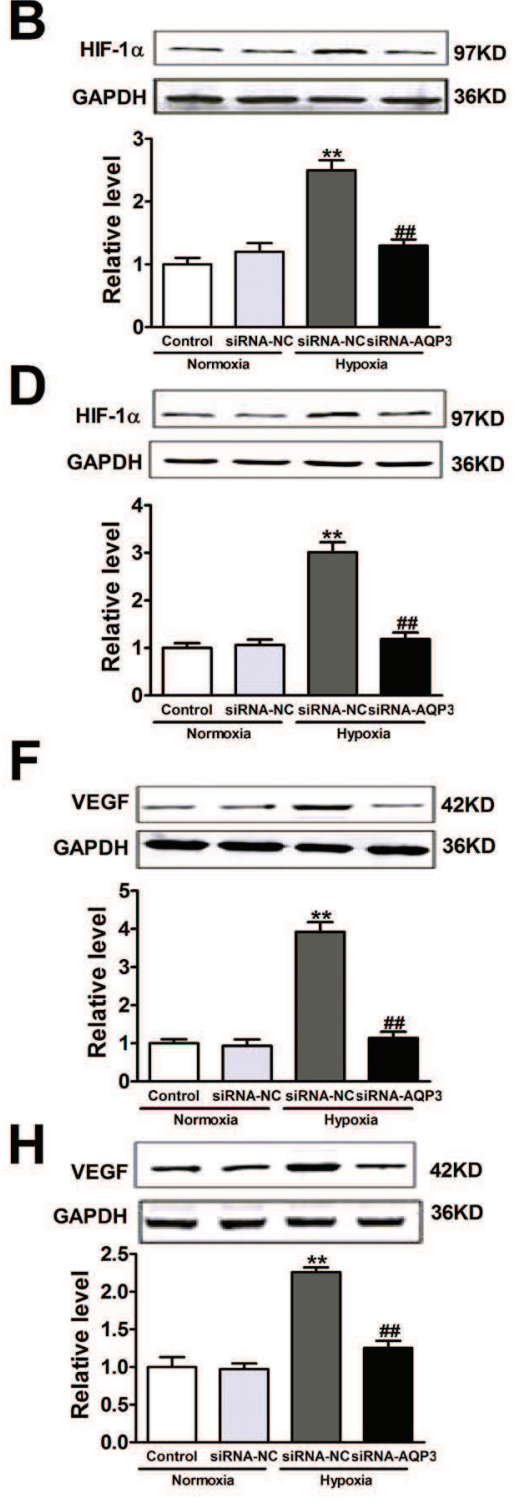

AQP3 knockdown inhibited the mRNA and protein levels of HIF-1 $\alpha$ and VEGF

To validate the roles of HIF- $1 \alpha$ and VEGF in AQP3-mediated antiproliferation, western blotting and qRT-PCR were performed. The mRNA and levels of HIF-1 $\alpha$ and VEGF were measured in A549 and NCI-H460 cells transfected with AQP3 siRNA. The results showed that the mRNA level of HIF-1 $\alpha$ was substantially decreased by AQP3 knockdown (Fig. 5A and C). Similarly, AQP3 knockdown clearly reduced hypoxic conditions and mediated the protein upregulation of HIF- $1 \alpha$ in A549 and NCI-H460 cells (Fig. 5B and D). To further investigate whether VEGF is involved in AQP3-mediated cellular effects, we detected mRNA and protein expression of VEGF after AQP3 siRNA transfection. The results showed that AQP3 knockdown substantially decreased the mRNA and protein expression of VEGF in A549 and NCI-H460 cells, respectively (Fig. 5E, F and G, H).

Downregulation of AQP3 suppressed levels of Raf and phospho-MEK (p-MEK) and phospho-ERK ( $p$-ERK)

To confirm the regulatory effects of AQP3 on Raf, p-MEK, and p-ERK in A549 and $\mathrm{NCI}-\mathrm{H} 460$ cells, changes in Raf, p-MEK, and p-ERK protein levels following transfection 


\section{Cellular Physiology Cell Physiol Biochem 2016;38:129-140 \begin{tabular}{ll|l}
\hline DOI: 10.1159/000438615 & O 2016 The Author(s). Published by S. Karger AG, Basel \\
\hline
\end{tabular}

Fig. 6. Effect of $\mathrm{AQP3}$ knockdown on levels of Raf, phospho-MEK (pMEK) and phopho-ERK (p-ERK). The levels of Raf, Total-MEK (T-MEK), p-MEK, Total-ERK (TERK), and p-ERK were measured in western blotting assays. The results showed that AQP3 knockdown significantly inhibited levels of Raf, p-MEK and p-ERK in A549 cells (A, D and $\mathrm{H}$ ) and NCI-H460 cells (B, $\mathrm{F}$ and J), respectively. In addition, figures $\mathrm{C}$, G (A549 cells) and E, I (NCI-H460 cells) show that protein levels of $\mathrm{T}$ MEK, T-ERK had no noticeable changes.. All of the values are denoted as the mean $\pm \mathrm{SEM}$; ${ }^{* *} p$ $<0.01$ vs. siRNA-NC of normoxia, \#\# $p<0.01$ vs. siRNA-NC of hypoxia; experiments were repeated three times.
A

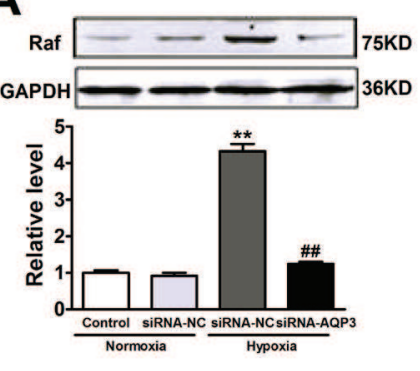

C

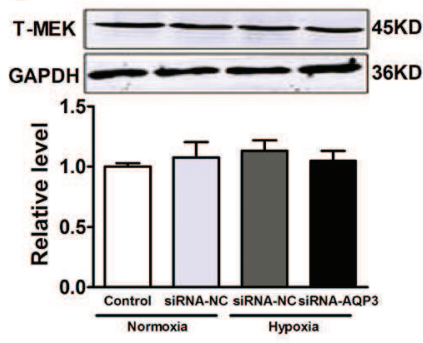

E
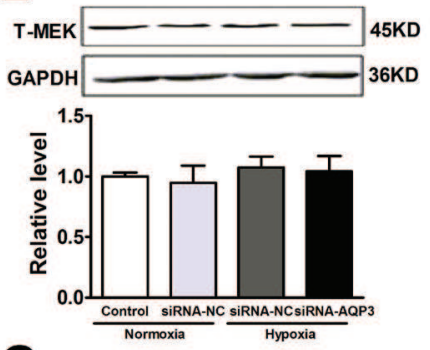

G
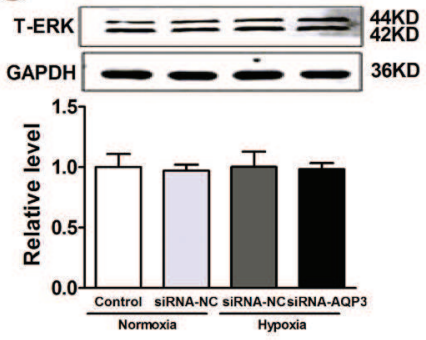

I
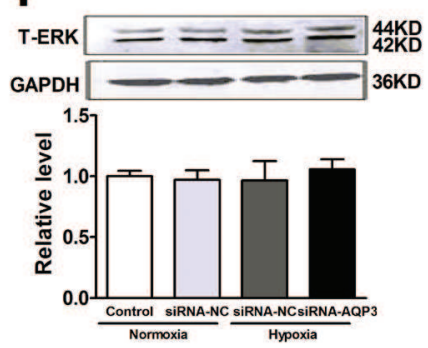

B

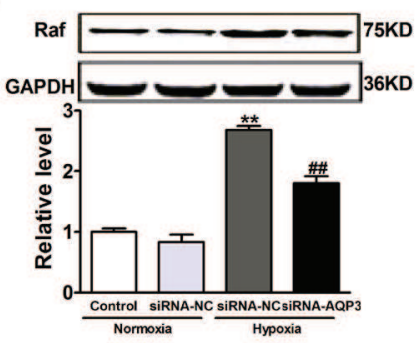

D

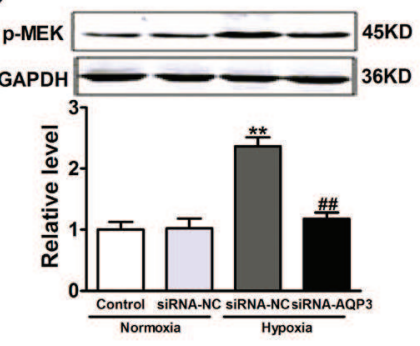

F

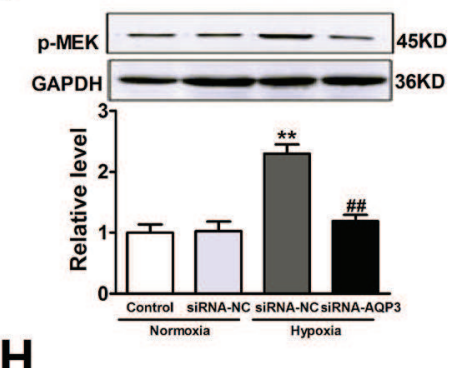

H
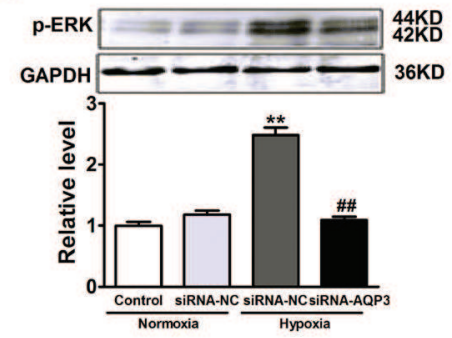

J
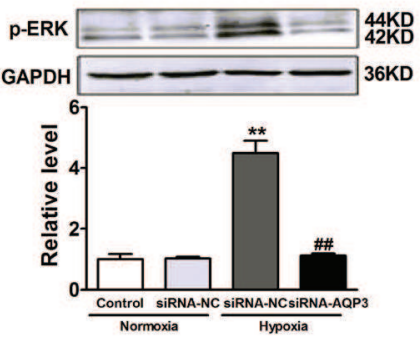

with AQP3 were measured. After transfection with the AQP3 siRNA, the protein levels of Raf were decreased in the A549 cells (Fig. 6A). Similar results were also identified in the NCI-H460 cells (Fig. 6B). In addition, the levels of both p-MEK and p-ERK were reduced after transfection with the AQP3 siRNA in the A549 (Fig. 6D and H) and NCI-H460 cells (Fig. 6F and J). However, the total levels of MEK and ERK did not change between different groups in 


\section{Cellular Physiology Cell Physiol Biochem 2016;38:129-140 \\ \begin{tabular}{ll|l} 
and Biochemist 10.1159/000438615 & $\begin{array}{l}\text { O } 2016 \text { The Author(s). Published by S. Karger AG, Basel } \\
\text { www.karger.com/cpb }\end{array}$ \\
\hline
\end{tabular} \\ Hou et al.: Aquaporin-3 Knockdown Retards the NSCLC Cells Growth}

the A549 (Fig. 6C and G) and NCI-H460 cells (Fig. 6E and I). These results suggested that the effects of AQP3 knockdown are at least partly the result of the regulation of the Raf/MEK/ ERK pathway.

\section{Discussion}

Lung cancer is one of the most prevalent malignancies worldwide. One class of lung cancer, NSCLCs, is relatively insensitive to chemotherapy and radiation compared with small cell carcinoma [22, 23]. Thus, clarifying the carcinogenic mechanisms and the potential treatment targets are critical. Hypoxia is a common phenomenon occurring in most human tumours, including NSCLCs. It has been proven to play a pivotal role in tumour progression and chemo- or radio-resistance [24]. However, the regulatory mechanisms involved in hypoxia still remain largely unknown.

The aquaporins (AQPs), a large family of "water channels", are conserved throughout animals, lower organisms, and plants. Recently, AQPs have been recognized as potential modulators in therapy for some types of refractory edema, brain swelling, neuroinflammation, pain, obesity, and even cancer [25]. Recent evidence has suggested that AQPs are involved in the regulation of cancer cell proliferation, migration and invasion [11, 17, 26-28].

AQP3 belongs to the family of "water channels", and it often participates in the regulation of various cellular processes in cancer. Recently, in urothelial bladder cancer patients, Denzinger et al. [29] have indicated that 59\% of patients exhibit AQP3-positive tumours. In hepatocellular carcinoma (HCC) patients, Gao et al. [30] have found that HCC patients expressing high levels of AQP3 protein have poorer 5-year disease-free survival and 5-year overall survival. Although multiple studies support the role of AQP3 in cell proliferation, several studies have indicated contrasting effects. Choudhary et al. [31] have indicated that re-expression of AQP3 has no effect on the expression of the proliferation makers keratin 5 and cyclin D1. Matsuo et al. [32] have suggested that decreased AQP3 expression is related to a more aggressive tumour behaviour. Recently, Kim et al. [33] have described that reduced AQP3 inhibits expression of phosphorylated PI3K, E-cadherin, $\beta$-catenin and decreases cell survival. Thus, the mechanisms of AQP3 remain to be uncovered. Recently, Katoh et al. [13] have identified AQP3 expression in 100\% of their tested samples from pituitary adenomas, thymomas, thymic carcinomas, and pulmonary adenocarcinomas. In pulmonary adenocarcinomas, $\mathrm{AQP} 3$ has been detected in all the tumours within the bronchioloalveolar subtype. In contrast, AQP3 is scarcely detected in small cell carcinoma, pleomorphic carcinoma, or metastatic colon adenocarcinoma [34]. This study, for the first time, investigated the role of AQP3 in proliferation, migration, and invasion, and determined potential mechanisms of the AQP3 in A549 and $\mathrm{NCl}-\mathrm{H} 460$ cell lines under hypoxic conditions. The results showed that $\mathrm{AQP} 3$ knockdown substantially reduced proliferation, migration and invasion in both the A549 and NCI-H460 cells (Fig. 2, 3 and 4). The mechanisms underlying the regulation of A549 and NCI-H460 cell proliferation, migration and invasion by AQP3 are often attributed to targeting important factors or key pathways. HIF-1 $\alpha$ is considered to be the master transcriptional regulator of cellular, developmental and pathological responses to hypoxia [35]. In most situations, HIF-1 $\alpha$ is rapidly degraded under normoxic conditions, but its level accumulates under hypoxic conditions. Recently, Wu et al. [36] manifested that high HIF-1 $\alpha$ expressions had a significantly higher chance to be non-responder to chemotherapy in NSCLC patients. Therefore, we speculated that HIF-1 $\alpha$ might be involved in AQP3 mediated cellular effects. In this study, we identified that AQP3 knockdown markedly reduced the expression of HIF- $1 \alpha$ (Fig. 5). Notably, HIF- $1 \alpha$ binds to the VEGF promoter and enhances its transcription [37], which is closely associated with proliferation, migration, invasion, angiogenesis and poor prognosis in cancer [38-41]. As expected, the results showed that AQP3 knockdown inhibited VEGF protein levels (Fig. 5F and H). Aberrantly expressed HIF- $1 \alpha$ often participates in the regulation of lung cancer cells survival/death [42]. A recent report has shown that during hypoxic conditions, the Raf-MEK-ERK signalling pathway is 


\section{Cellular Physiology Cell Physiol Biochem 2016;38:129-140

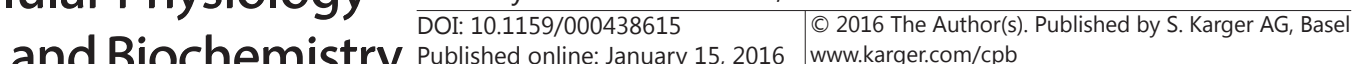 \\ Hou et al.: Aquaporin-3 Knockdown Retards the NSCLC Cells Growth}

activated. The activation of this pathway leads to angiogenesis and uncontrolled growth of cells [43]. Thus, it is conceivable that increased levels of Raf-MEK-ERK may be induced by the loss of AQP3 expression in tumour cells. In the present study, after introducing an AQP3 knockdown, the level of Raf was clearly inhibited. In addition, p-MEK and p-ERK were both downregulated with no significant changes in total-MEK and total-ERK (Fig. 6).

Though AQP3 downregulation exerts anticancer properties, more in vivo studies and related molecular mechanisms are need to further investigate and determine the molecular mechanisms of AQP3 in NSCLCs and other types of cancers. Moreover, the effect of AQP3 on migration closely parallels on proliferation, while the current data do not allow ruling out interdependence between the increase in the number of cells and in migration. Therefore, it is still need to further define the effect of AQP3 on migration and proliferation in NSCLCs in future. As mentioned above, AQP3 knockdown inhibited the growth of NSCLC cells under hypoxic conditions, which was associated with the HIF-1 $\alpha$ /VEGF and Raf-MEK-ERK pathways. Our findings provide insight about new regulatory mechanisms involved in hypoxia and evidence for the participation of AQP3 in NSCLCs and as a therapeutic target for NSCLCs.

\section{Abbreviations}

Non-small-cell lung cancer (NSCLC); Aquaporin-3 (AQP3); Hypoxia-inducible Factor $1 \alpha$ (HIF-1 $\alpha$ ); Vascular Endothelial Growth Factor (VEGF).

\section{Acknowledgements}

This work was supported by the Heilongjiang Postdoctoral Financial Assistance (LBH-Z12170) and the Health and Family Planning Commission of Heilongjiang Province (2011-119).

\section{Disclosure Statement}

None.

\section{References}

1 Peters S, Adjei AA, Gridelli C, Reck M, Kerr K, Felip E: Metastatic non-small-cell lung cancer (NSCLC): ESMO Clinical Practice Guidelines for diagnosis, treatment and follow-up. Ann Oncol 2012;23:vii56-64.

2 Borgnia M, Nielsen S, Engel A, Agre P: Cellular and molecular biology of the aquaporin water channels. Annu Rev Biochem 1999;68:425-458.

3 Loreto C, Reggio E: Aquaporin and vascular diseases. Curr Neuropharmacol 2010;8:105-111.

4 Papadopoulos MC, Verkman AS: Aquaporin water channels in the nervous system. Nat Rev Neurosci 2013;14:265-277.

5 Ishikawa Y, Cho G, Yuan Z, Skowronski MT, Pan Y, Ishida H: Water channels and zymogen granules in salivary glands. J Pharmacol Sci 2006;100:495-512.

6 Hoque MO, Soria JC, Woo J, Lee T, Lee J, Jang SJ, Upadhyay S, Trink B, Monitto C, Desmaze C, Mao L, Sidransky D, Moon C: Aquaporin 1 is overexpressed in lung cancer and stimulates NIH-3T3 cell proliferation and anchorage-independent growth. Am J Pathol 2006;168:1345-1353.

7 Zhu SJ, Wang KJ, Gan SW, Xu J, Xu SY, Sun SQ: Expression of aquaporin8 in human astrocytomas: correlation with pathologic grade. Biochem Biophys Res Commun 2013;440:168-172. 


\section{Cellular Physiology Cell Physiol Biochem 2016;38:129-140 \begin{tabular}{ll|l} 
DOI: 10.1159/000438615 & ( ) 2016 The Author(s). Published by S. Karger AG, Basel
\end{tabular} and Biochemistry Published online: January 15, 2016 www.karger.com/cpb \\ Hou et al.: Aquaporin-3 Knockdown Retards the NSCLC Cells Growth}

8 Kang BW, Kim JG, Lee SJ, Chae YS, Jeong JY, Yoon GS, Park SY, Kim HJ, Park JS, Choi GS: Expression of aquaporin-1, aquaporin-3, and aquaporin-5 correlates with nodal metastasis in colon cancer. Oncology 2015;88:369-376.

9 Verkman AS, Hara-Chikuma M, Papadopoulos MC: Aquaporins--new players in cancer biology. J Mol Med (Berl) 2008;86:523-529.

$10 \mathrm{Hu}$ J, Verkman AS: Increased migration and metastatic potential of tumor cells expressing aquaporin water channels. FASEB J 2006;20:1892-1894.

11 Huang YT, Zhou J, Shi S, Xu HY, Qu F, Zhang D, Chen YD, Yang J, Huang HF, Sheng JZ: Identification of Estrogen Response Element in Aquaporin-3 Gene that Mediates Estrogen-induced Cell Migration and Invasion in Estrogen Receptor-positive Breast Cancer. Sci Rep 2015;5:12484.

12 Li A, Lu D, Zhang Y, Li J, Fang Y, Li F, Sun J: Critical role of aquaporin-3 in epidermal growth factor-induced migration of colorectal carcinoma cells and its clinical significance. Oncol Rep 2013;29:535-540.

13 Niu D, Kondo T, Nakazawa T, Yamane T, Mochizuki K, Kawasaki T, Matsuzaki T, Takata K, Katoh R: Expression of aquaporin3 in human neoplastic tissues. Histopathology 2012;61:543-551.

14 Chen J, Wang Z, Xu D, Liu Y, Gao Y: Aquaporin 3 promotes prostate cancer cell motility and invasion via extracellular signal-regulated kinase 1/2-mediated matrix metalloproteinase-3 secretion. Mol Med Rep 2015;11:2882-2888.

15 Nakahigashi K, Kabashima K, Ikoma A, Verkman AS, Miyachi Y, Hara-Chikuma M: Upregulation of aquaporin-3 is involved in keratinocyte proliferation and epidermal hyperplasia. J Invest Dermatol 2011;131:865-873.

16 Chen J, Wang T, Zhou YC, Gao F, Zhang ZH, Xu H, Wang SL, Shen LZ: Aquaporin 3 promotes epithelialmesenchymal transition in gastric cancer. J Exp Clin Cancer Res 2014;33:38.

17 Xia H, Ma YF, Yu CH, Li YJ, Tang J, Li JB, Zhao YN, Liu Y: Aquaporin 3 knockdown suppresses tumour growth and angiogenesis in experimental non-small cell lung cancer. Exp Physiol 2014;99:974-984.

18 Fraga A, Ribeiro R, Principe P, Lopes C, Medeiros R: Hypoxia and Prostate Cancer Aggressiveness: A Tale With Many Endings. Clin Genitourin Cancer 2015;13:295-301.

19 Kim M, Park SY, Pai HS, Kim TH, Billiar TR, Seol DW: Hypoxia inhibits tumor necrosis factor-related apoptosis-inducing ligand-induced apoptosis by blocking Bax translocation. Cancer Res 2004;64:40784081.

20 Lee SL, Rouhi P, Dahl Jensen L, Zhang D, Ji H, Hauptmann G, Ingham P, Cao Y: Hypoxia-induced pathological angiogenesis mediates tumor cell dissemination, invasion, and metastasis in a zebrafish tumor model. Proc Natl Acad Sci USA 2009;106:19485-19490.

21 Fan Y, Chen M, Meng J, Yu L, Tu Y, Wan L, Fang K, Zhu W: Arsenic trioxide and resveratrol show synergistic anti-leukemia activity and neutralized cardiotoxicity. PLoS One 2014;9:e105890.

22 Storozhuk Y, Hopmans SN, Sanli T, Barron C, Tsiani E, Cutz JC, Pond G, Wright J, Singh G, Tsakiridis T: Metformin inhibits growth and enhances radiation response of non-small cell lung cancer (NSCLC) through ATM and AMPK. Br J Cancer 2013;108:2021-2032.

23 Preoperative chemotherapy for non-small-cell lung cancer: a systematic review and meta-analysis of individual participant data. Lancet 2014;383:1561-1571.

24 Harrison L, Blackwell K: Hypoxia and anemia: factors in decreased sensitivity to radiation therapy and chemotherapy? Oncologist 2004;9:31-40.

25 Verkman AS: Aquaporins in clinical medicine. Annu Rev Med 2012;63:303-316.

26 Nico B, Ribatti D: Aquaporins in tumor growth and angiogenesis. Cancer Lett 2010;294:135-138.

27 Zou LB, Zhang RJ, Tan YJ, Ding GL, Shi S, Zhang D, He RH, Liu AX, Wang TT, Leung PC, Sheng JZ, Huang HF: Identification of estrogen response element in the aquaporin-2 gene that mediates estrogen-induced cell migration and invasion in human endometrial carcinoma. J Clin Endocrinol Metab 2011;96:E1399-1408.

28 Machida Y, Ueda Y, Shimasaki M, Sato K, Sagawa M, Katsuda S, Sakuma T: Relationship of aquaporin 1, 3, and 5 expression in lung cancer cells to cellular differentiation, invasive growth, and metastasis potential. Hum Pathol 2011;42:669-678.

29 Otto W, Rubenwolf PC, Burger M, Fritsche HM, Rossler W, May M, Hartmann A, Hofstadter F, Wieland WF, Denzinger S: Loss of aquaporin 3 protein expression constitutes an independent prognostic factor for progression-free survival: an immunohistochemical study on stage pT1 urothelial bladder cancer. BMC Cancer 2012;12:459. 


\section{Cellular Physiology Cell Physiol Biochem 2016;38:129-140 \begin{tabular}{l|l|l}
\cline { 2 - 3 } DOI: 10.1159/000438615 & (c) 2016 The Author(s). Published by S. Karger AG, Basel
\end{tabular} and Biochemistry Published online: January 15, 2016 www.karger.com/cpb}

Hou et al.: Aquaporin-3 Knockdown Retards the NSCLC Cells Growth

30 Guo X, Sun T, Yang M, Li Z, Gao Y: Prognostic value of combined aquaporin 3 and aquaporin 5 overexpression in hepatocellular carcinoma. Biomed Res Int 2013;2013:206525.

31 Choudhary V, Olala LO, Qin H, Helwa I, Pan ZQ, Tsai YY, Frohman MA, Kaddour-Djebbar I, Bollag WB: Aquaporin-3 re-expression induces differentiation in a phospholipase D2-dependent manner in aquaporin3-knockout mouse keratinocytes. J Invest Dermatol 2015;135:499-507.

32 Matsuo K, Kawano K: Immunohistochemical distribution and morphometric analysis of aquaporin-3 in oral squamous cell carcinoma. Int J Oral Maxillofac Surg 2014;43:13-21.

33 Kim NH, Lee AY: Reduced aquaporin3 expression and survival of keratinocytes in the depigmented epidermis of vitiligo. J Invest Dermatol 2010;130:2231-2239.

34 Liu YL, Matsuzaki T, Nakazawa T, Murata S, Nakamura N, Kondo T, Iwashina M, Mochizuki K, Yamane T, Takata K, Katoh R: Expression of aquaporin 3 (AQP3) in normal and neoplastic lung tissues. Hum Pathol 2007;38:171-178.

35 Carmeliet P, Dor Y, Herbert JM, Fukumura D, Brusselmans K, Dewerchin M, Neeman M, Bono F, Abramovitch R, Maxwell P, Koch CJ, Ratcliffe P, Moons L, Jain RK, Collen D, Keshert E: Role of HIF-1alpha in hypoxiamediated apoptosis, cell proliferation and tumour angiogenesis. Nature 1998;394:485-490.

36 Wu F, Zhang J, Liu Y, Zheng Y, Hu N: HIF1alpha genetic variants and protein expressions determine the response to platinum based chemotherapy and clinical outcome in patients with advanced NSCLC. Cell Physiol Biochem 2013;32:1566-1576.

37 Jiang BH, Rue E, Wang GL, Roe R, Semenza GL: Dimerization, DNA binding, and transactivation properties of hypoxia-inducible factor 1. J Biol Chem 1996;271:17771-17778.

38 Kim JJ, Vaziri SA, Rini BI, Elson P, Garcia JA, Wirka R, Dreicer R, Ganapathi MK, Ganapathi R: Association of VEGF and VEGFR2 single nucleotide polymorphisms with hypertension and clinical outcome in metastatic clear cell renal cell carcinoma patients treated with sunitinib. Cancer 2012;118:1946-1954.

39 Chen J, Tang D, Wang S, Li QG, Zhang JR, Li P, Lu Q, Niu G, Gao J, Ye NY, Wang DR: High expressions of galectin-1 and VEGF are associated with poor prognosis in gastric cancer patients. Tumour Biol 2014;35:2513-2519.

40 Carmeliet P: VEGF as a key mediator of angiogenesis in cancer. Oncology 2005;69:4-10.

41 Lu KV, Chang JP, Parachoniak CA, Pandika MM, Aghi MK, Meyronet D, Isachenko N, Fouse SD, Phillips JJ, Cheresh DA, Park M, Bergers G: VEGF inhibits tumor cell invasion and mesenchymal transition through a MET/VEGFR2 complex. Cancer Cell 2012;22:21-35.

42 Volm M, Koomagi R: Hypoxia-inducible factor (HIF-1) and its relationship to apoptosis and proliferation in lung cancer. Anticancer Res 2000;20:1527-1533.

43 Shen K, Ji L, Gong C, Ma Y, Yang L, Fan Y, Hou M, Wang Z: Notoginsenoside Ft1 promotes angiogenesis via HIF-1alpha mediated VEGF secretion and the regulation of PI3K/AKT and Raf/MEK/ERK signaling pathways. Biochem Pharmacol 2012;84:784-792. 